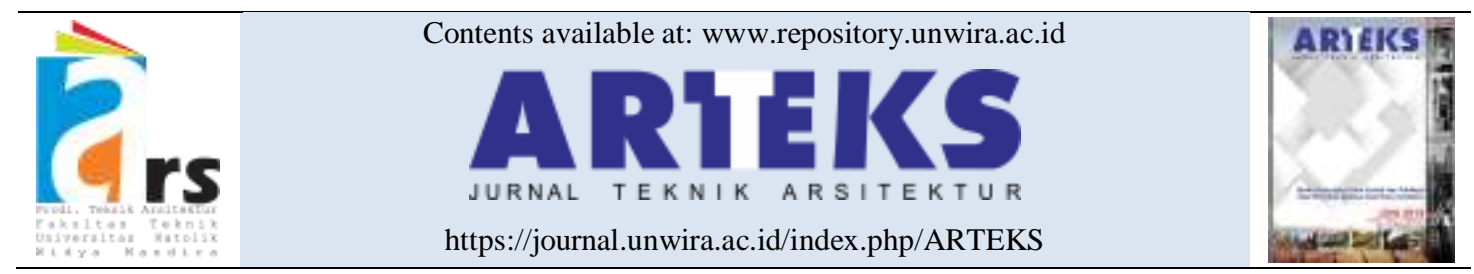

Research paper

doi: $10.30822 /$ arteks.v6i3.833

\title{
The effect of public park boundary order on the environmental control of local government central offices
}

\author{
A case study of City Halls in Bandung, Surabaya, and Semarang
}

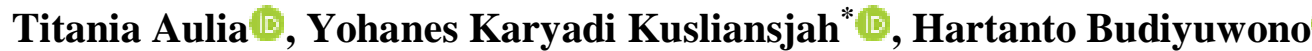 \\ Architecture Study Program, Faculty of Engineering, Universitas Katolik Parahyangan \\ Jl. Ciumbuleuit no. 94, Bandung, Indonesia
}

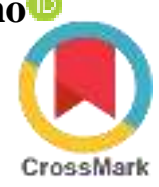

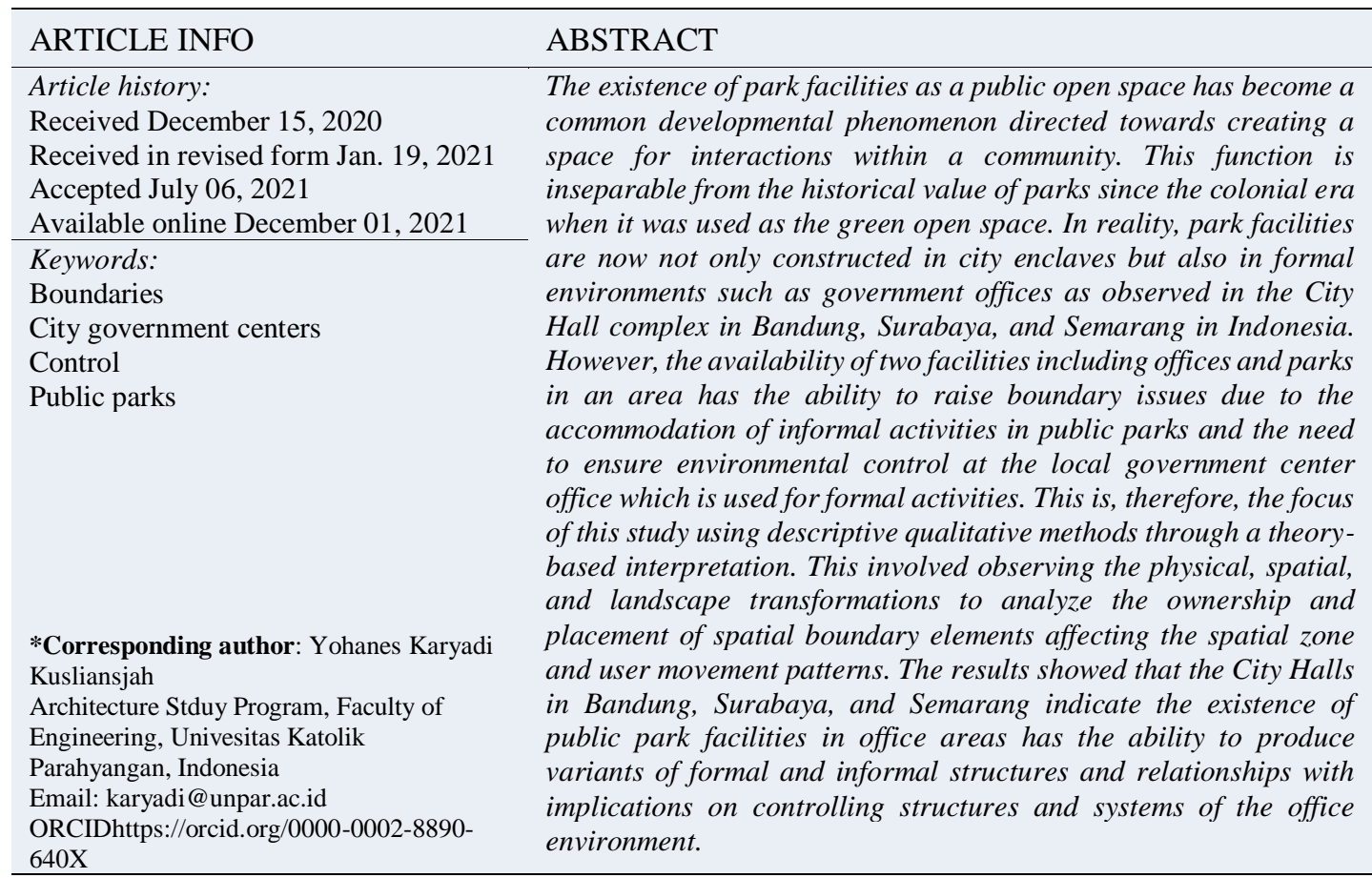

\section{Introduction}

Public open space is one of the most important architectural components in the environmental and behavioral relationship due to its ability to function as a forum for human activity (Hantono 2019; Hartoyo and Santoni 2018), both formal and informal (Liem and Lake 2018; Dianty and Dwisusanto 2020). It represents the desire of urban people to interact with nature in order to create a recreational effect on their busy lives (Irfandi et al. 2017). The terms formal and informal are concepts closely related to human social activities as the space users from the architectural perspective. It is important to note that the formal aspect involves a consciously coordinated system of activities while the informal is the opposite (Laguerre 1994). Meanwhile, a local government center building is a formal facility which is always available in an urban area.

Offices are an example of formal facilities while parks are informal facilities accommodating flexibility, unlimited activities, and are slightly unstructured systems (Laguerre 1994). The parks have been reported to have activities needed by humans in the city to engage 
in interactions (Maslow 1954). They are generally an important part of modern metropolitan infrastructures designed to significantly support and influence the entire physical, social, and mental areas of the city. The concept is expected not only to be used to preserve the environment but also as an artifact explicitly created to actively accommodate human activities (Garvin 2011).

The government requires every city to allocate at least $30 \%$ of its territory for green open space (RTH) out of which $20 \%$ is owned and managed by the government city according to Law (UU) Number 26 of 2007 article 29 for the benefit of society in general (Wibowo and Ritonga 2018). The development of lifestyle and community needs is increasing the placement of public space facilities in the form of parks in urban areas. The structures are, however, currently not focused only on city enclaves but also in formal complexes such as offices at the City Hall.

The provision of public parks with several facilities in formal office areas has a physical order which affects the form, control, and patterns of activity influenced by access, transitional space, and boundary elements. Patterns of activity in public facilities do not affect only the public space but also have an influence on the environment as observed with the formation of the order in the surrounding buildings (Viantara 2020). This order, however, forms a visual, which according to Hanan (2013), has the ability to provide a certain physical-spatial pattern affecting the user's movement based on the existing boundary elements. It is, therefore, necessary to predetermine the elements of spatial boundaries, factors determining the boundary structure in realizing control, as well as the realization of a public park in an office environment through coherent systemization.

This research was conducted to compare the embodiment of the City Halls objects which are related to the physical order and affecting the environmental control of the office as an existing structure. The factors considered include the degree of openness, flexibility, and movement patterns. Moreover, this study also complements the discussions on the issue of public parks in urban areas with an even more specific scope which is the placement of these facilities within the government environment such as the City Hall. For the purpose of this study, Bandung, Surabaya, and Semarang City Halls were selected as a case study due to the fact that they have imposed public parks and are observed to be at the same level by being capital cities. The result is expected to serve as a reference in planning public parks in an office environment, especially from a physical-spatial perspective.

\section{Method}

This research was conducted using the descriptive qualitative method with an analytical approach based on object data and literature studies after which the conclusions were described interpretatively. First, the ownership and placement of spatial boundary elements were examined. Second, the effect of the spatial boundary elements on the space zone and user movement patterns was determined. Third, each of the elements was compared to know the variants of the public park's layout in the City Halls complex in order to understand their respective embodiment in controlling the office environment structure and system. Meanwhile, Bandung, Surabaya, and Semarang were selected as case studies based on the fact that they were capital cities and have similar public parks in the local government center offices or City Hall.

\section{Data collection method}

Data were collected through direct observation of the Bandung City Hall before the pandemic and indirect observation of Surabaya and Semarang City Halls based on current sources including journals, documentation, and the internet starting from January 2020. The two city halls were indirectly observed due to the Covid19 pandemic situation which made it impossible to directly access the sites as well as the restrictions of activities in park facilities. Furthermore, data were also collected to understand the definitions and references related to research variables with a focus on physicalspatial forms, environmental arrangements towards control, and overall user movement patterns without culture.

The observations were made during weekdays starting Monday to Friday and between $2.00 \mathrm{pm}$ and $4.00 \mathrm{pm}$ due to the existence of both formal and informal activities during this period.

Data analysis method

Data obtained were analyzed using object data and theoretical triangulations in relation to the form and control as well as the spatial boundary 
elements described in interpretive descriptive. The process involved tracing the "Nominal Class" vertically and "Configuration" horizontally. The nominal class was, however, evaluated by examining the physical-spatial transformations and functions of each study object through the details of urban frames related to 'mass' and 'circulation' of current landscape layouts in order to determine the ownership and placement of spatial boundaries elements. Moreover, this search was used to understand the implications of the 'boundary' element on the movement patterns of users including office staff and the general public, supported by a figure-ground solid-void map (Trancik 1986).

This search produced a configuration which was used to determine the structural factors in physical and spatial terms in relation to the existence of user control over space due to the configuration of these physical elements (Bukit, Hanan, and Wibowo 2012). This was further used in the final stage to horizontally compare the three study objects regarding the realization of office control due to the addition of public park facilities in the environment. The overall description is, however, traceable as indicated in the following figure 1 .

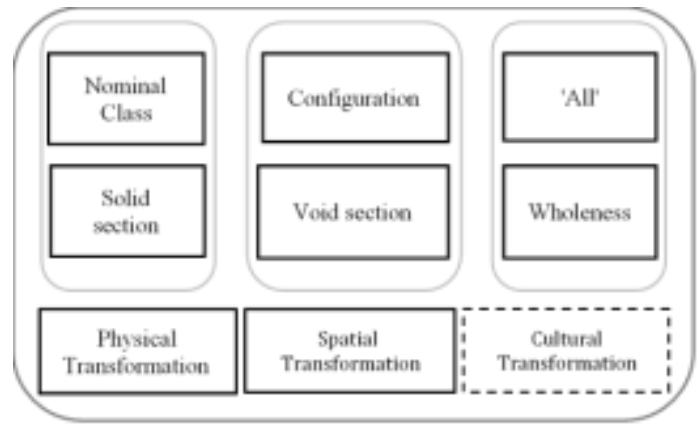

Figure 1. Tracing aspects of form and control of public park facilities added to government spaces

Source: Bukit, Hanan, and Wibowo (2012) based on Habraken (1998)

Figure 1 serves as the basis for the main theory to thoroughly describe the aspects discussed in the research. The 'Nominal Class' aspect has certain component items used as a reference in line with Thoreau (1983) which were grouped into a gradual analysis component as follows:

Table 1. Grouping of nominal class components based on Thoreau (1983)

Stage 1: Ownership analysis and Stage 2: Analysis of the effect of spatial spatial boundary element positioning

\section{Form generator}

Historic massing

Gateway and barriers

Center and nodes

Connector, lines and interchanges

Pedestrian and bicycle

Parking requirements

Building prototypes and groupings

Physical facilities

Emergency or safety
Stage 3: Analysis of the embodimen of order on environmental system control

Zoning, building, heights, and f. a. ratio Density, proportion, scale, and rhythm

Transitional zones and flexibility Urban frame analysis

Spatial sequence, views and vistas Traffic projector

Adjacency condition, hard and soft Public transportation (network and

Interface and interaction of above capacity)

Regional interface and interaction

Access pattern (origin-destination)

Physical form of network
The items grouped were narrowed to become more specific analytical components as follows:

Table 2. Main components of nominal classes stage 1 for understanding ownership and positioning based on Thoreau (1983)

\begin{tabular}{lll}
\hline No & Items & Component \\
\hline 1 & $\begin{array}{l}\text { Form generator and } \\
\text { historic massing }\end{array}$ & $\begin{array}{l}\text { Area Scope and } \\
\text { Shape }\end{array}$ \\
\hline 2 & Gateway and barriers & $\begin{array}{l}\text { Exit-entry access } \\
\text { and barriers }\end{array}$ \\
\hline 3 & Center and nodes & Point and center \\
\hline 4 & $\begin{array}{l}\text { Connector, lines and } \\
\text { interchanges } \\
\text { pedestrian and bicycle } \\
\text { parking requirements }\end{array}$ & $\begin{array}{l}\text { Lanes and parking } \\
\text { areas }\end{array}$ \\
\hline
\end{tabular}

\begin{tabular}{lll}
\hline No & Items & Component \\
\hline 5 & Building prototypes and & Buildings and mass \\
& groupings & \\
& physical facilities \\
emergency or safety & \\
\hline
\end{tabular}

Table 3. Description of nominal classes stage 2 components to understanding the implications based on Thoreau (1983)

\begin{tabular}{lll}
\hline No & Items & Component \\
\hline 1 & $\begin{array}{l}\text { Zoning, building, heights } \\
\text { and f. a. ratio } \\
\text { transitional zones and } \\
\text { flexibility }\end{array}$ & $\begin{array}{l}\text { Environmental } \\
\text { zoning and } \\
\text { transition zone }\end{array}$ \\
\hline 2 & $\begin{array}{l}\text { Spatial sequence, views } \\
\text { and vistas }\end{array}$ & Spatial order \\
\hline 3 & $\begin{array}{l}\text { Adjacency condition, hard } \\
\text { and soft interface and }\end{array}$ & $\begin{array}{l}\text { Achievements and } \\
\text { interactions }\end{array}$ \\
\hline
\end{tabular}




\begin{tabular}{lll}
\hline No & Items & Component \\
\hline & $\begin{array}{l}\text { interaction of above } \\
\text { regional interface and } \\
\text { interaction }\end{array}$ & \\
\hline 4 & $\begin{array}{l}\text { Access pattern (origin- } \\
\text { destination) } \\
\text { physical form of network }\end{array}$ & $\begin{array}{l}\text { Access patterns and } \\
\text { physical form of the } \\
\text { network }\end{array}$ \\
\hline
\end{tabular}

Table 4. Formation of nominal classes stage 3 components to trace the City Hall Formation based on Thoreau (1983)

\begin{tabular}{|c|c|c|}
\hline No & Items & Component \\
\hline 1 & $\begin{array}{l}\text { Density, proportion, scale, } \\
\text { and rhythm }\end{array}$ & $\begin{array}{l}\text { Determined through } \\
\text { Operational Hours } \\
\text { and Tickets as well } \\
\text { as Formal -Informal } \\
\text { Arrangements }\end{array}$ \\
\hline 2 & $\begin{array}{l}\text { Urban frame analysis } \\
\text { public transportation } \\
\text { (network and capacity) }\end{array}$ & $\begin{array}{l}\text { Determined through } \\
\text { overall physical } \\
\text { system and outer } \\
\text { space system }\end{array}$ \\
\hline
\end{tabular}

The 'nominal class' was further explored using the solid - void approach to determine the overall configuration including the comparison of factors, embodiments, and variants of the basic shapes produced based on environmental controls owned after the three stages. Meanwhile, the 'cultural' aspect was not included in the discussion because the research focuses only on 'physical' and 'Spatial' aspects without discussing the culture.

Object data

Bandung City Hall

Based on history, the Bandung City Hall was originally a building functioning as a coffee warehouse and managed by Andries de Wilde, a landlord from Priangan (Kunto 1984). It was, however, demolished in 1927 and finally changed to a major government building surrounded by gardens (Suriastuti, Wahjudi, and Handoko 2014). Meanwhile, the City Hall Park built in 1885 and known as Pieter Sijhoff Park was developed and expanded through the revitalization efforts of 2015 (Hidayati and Sugiarto 2020) and this involved the procurement of the Cikapayang River Park around the outer complex of City Hall, Historical Park, Bandung Tour on Bus (Bandros), and thematic park spots.

\section{Surabaya City Hall}

Based on history, the Surabaya City Hall was built in 1920 and completed in 1925 . The building was first known as the Gemeente Resort (1906) as part of the Gemeente Government's residency, run by the Gemeente Council, and chaired by the resident assistant serving as the regional head (site culture.id). The City Hall was built by G. C. Citroen that served as an architect with significant impact in the colonial era developments (Handinoto 1993). Meanwhile, a park area was constructed in line with the environmental plan of the City Hall by Citroen but now known and developed under the name Taman Surya with several other supporting facilities added to the original structure.

\section{Semarang City Hall}

It was discovered from history that Semarang City Hall has been moved due to fire incidences in 1850 and 1954. Meanwhile, the park area initially had no specific development goals other than to complement an existing building but continues to be developed to match the time and people's lifestyles up to the present City Hall Park. This development was through a revitalization project which was last implemented in 2017 (Irwanto 2017) as indicated by the modification of the yard shape with the addition of grass plots, fountains, and other facilities added to ensure the area becomes a space to conduct wider community activities.

\section{Result and discussion}

Analysis of nominal class at Bandung, Surabaya, and Semarang City Halls

The studies reviewed were observed to have discussed the following research topics:

Table 5. Research topics in the literature review

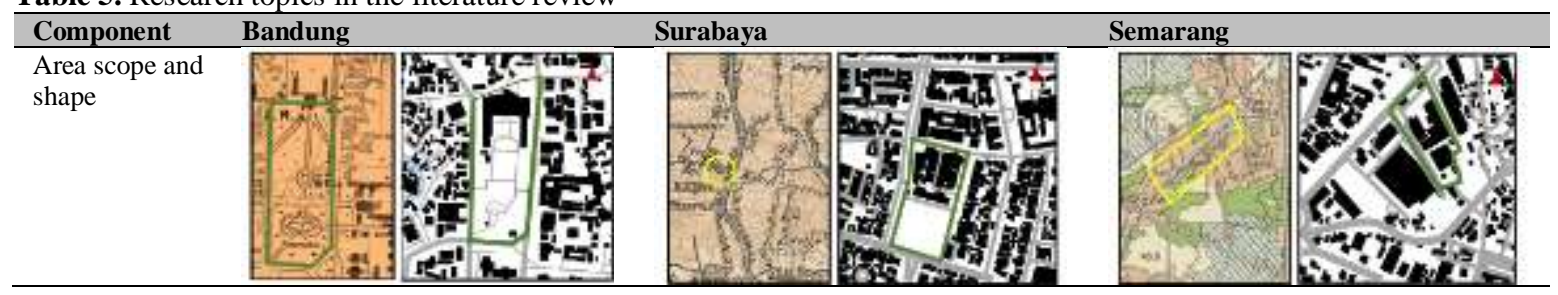




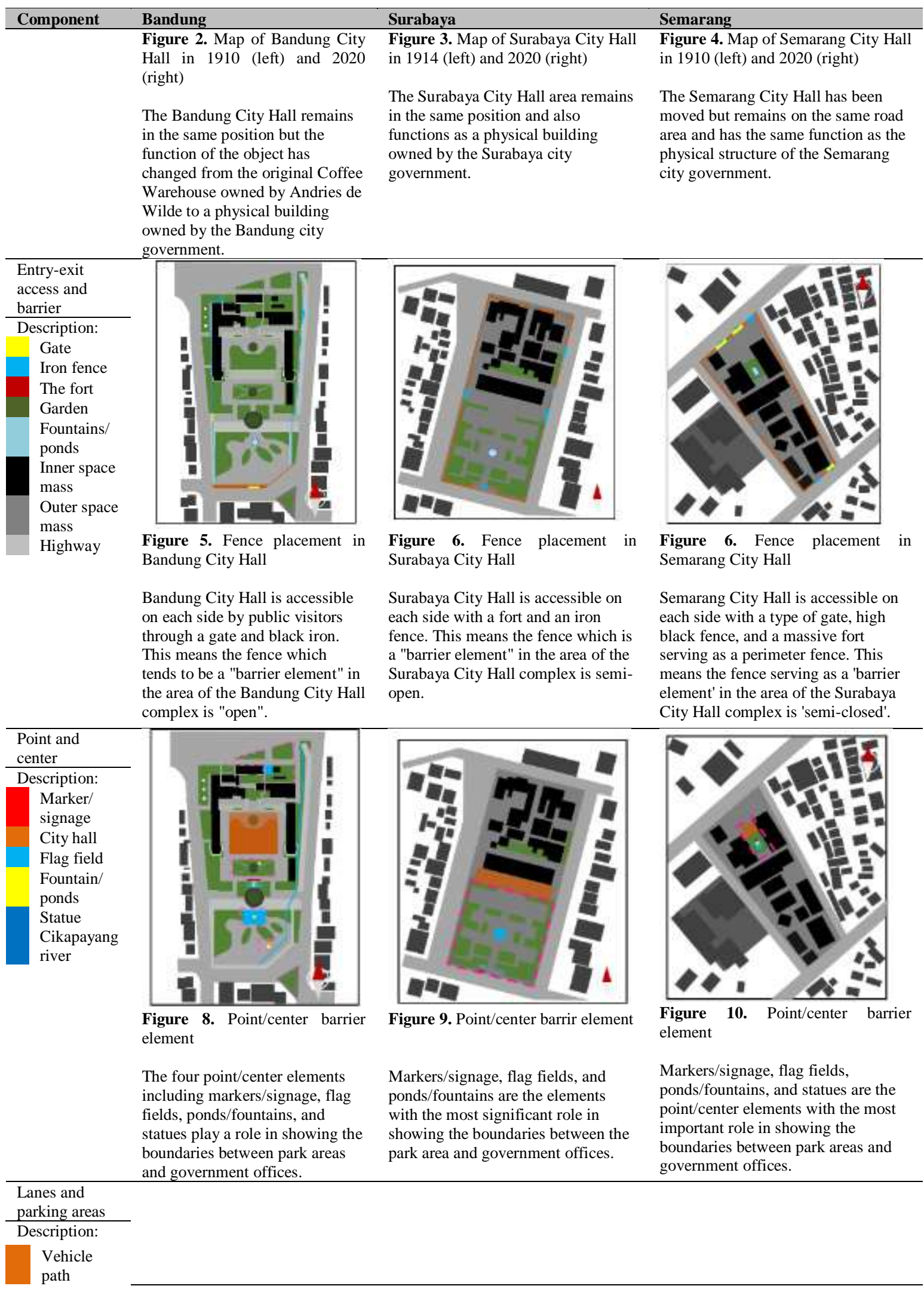




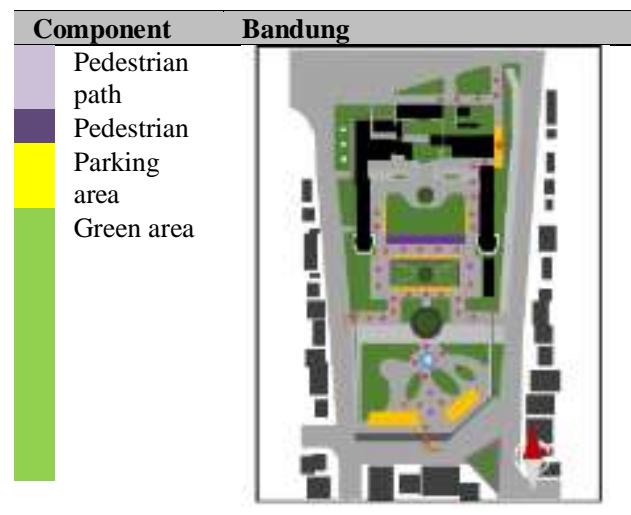

Figure 11. Placement of lines and parking areas

Bandung City Hall has a main route not only for those coming in with vehicles but also for pedestrians and this makes it a "mixed lane". Parking lots are in the central and southern areas of the complex and have special pavements with signs.

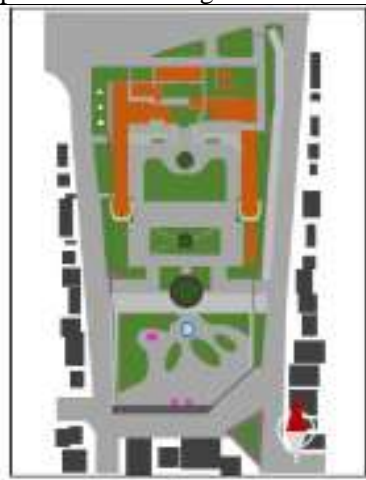

Figure 14. Placement of building and mass zoning

Bandung City Hall has masses scattered in its environment but the office mass arrangement tends to be "surrounded" by public park areas.

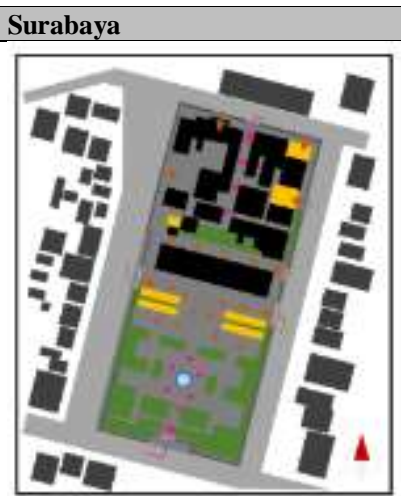

Figure 12. Placement of lines and parking areas

Surabaya City Hall has a path that tends to be 'concentrated'. This is indicated by the tendency of entryexit access for public visitors which takes precedence from the front (south) and the front side while office staff or interested visitors can access the back and rear side doors.

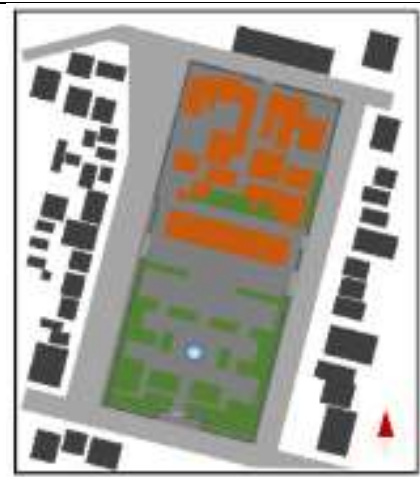

Figure 15. Placement of building and mass zoning

Surabaya City Hall has a mass divided into offices and parks.

Meanwhile, the office mass structure tends to adjust the scope of the area to the North.

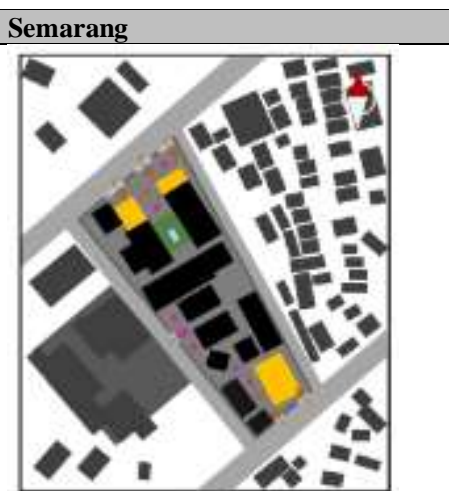

Figure 13. Placement of lines and parking areas

Semarang City Hall has a 'mixed lane' tendency due to the position of the parking lots in the front and rear area. The park is in the front area while the visitor parking building is at the back. This allows visitors to see the back-complex area before going to the front area.

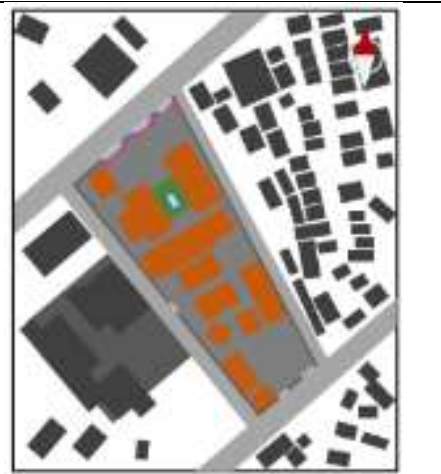

Figure 16. Placement of building and mass zoning

Semarang City Hall has masses scattered in its environment but the office mass arrangement tends to be "surrounded" by public park areas.

Source: Old map component 1 from poestahadepok.blogspot.com is based on the compilation of Harahap (2017) with reference to tempo doloe, Dutch East Indies Maps in Batavia, Antique Map of Batavia, Semarang and Surabaya by Wolters 'circa 1910', and Google Earth

The items of the component in table 6 were further analyzed as follows: 
Table 6. Analysis of the environment zoning and transition zone

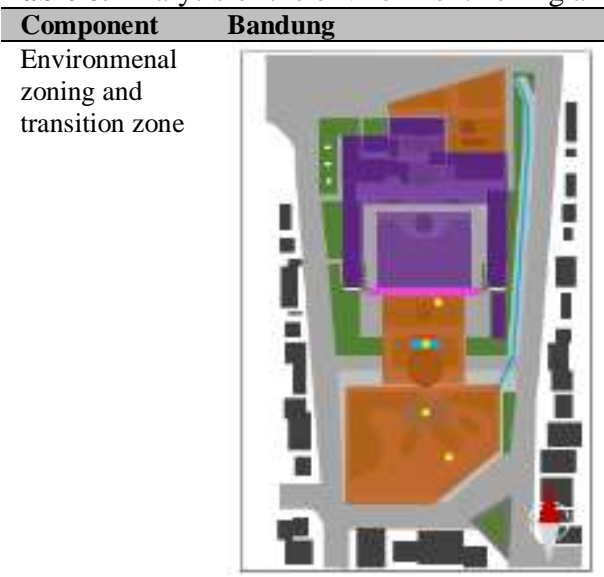

Figure 17. Formal and informal zoning

\section{Overall zoning: Mixed}

This provides flexible space for entry-exit access within the complex. This has the potential to disrupt the activities in the government office zone.

Layout and spatial boundary elements that become the transition zone:

The central area of the complex has signage that reads "City Hall Park"

Leveling area observed to be close to the city government offices

The statue points showing the landmarks

\section{Surabaya}

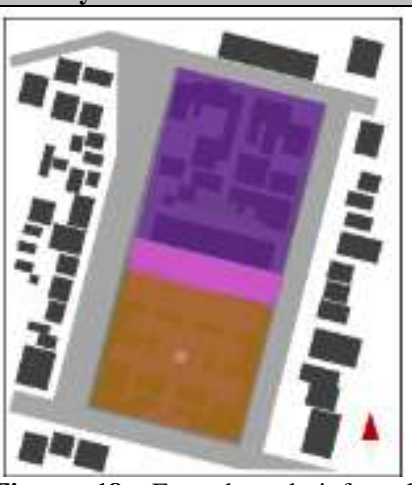

Figure 18. Formal and informal zoning

Overall Zoning: Divided into office and recreation zones

This provides flexible but organized space and shows the activities in the City Hall complex are conducive because each area has its concentration zone.

Layout and spatial boundary elements that become the transition zone:

The central area of the complex has a side door which connects it with the vehicle or pedestrian lane between government offices and a park area which mediates between the formal and informal zones.

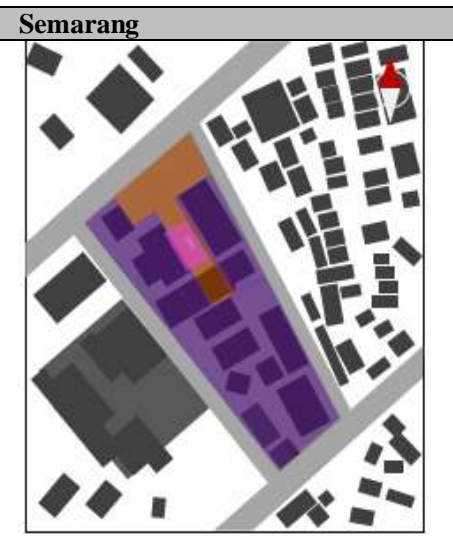

Figure 19. Formal and informal zoning

\section{Overall zoning: Mixed}

This provides less flexible space for entry-exit access in the complex as a whole. This has the potential to disrupt conducive conduct of activities in the formal zone with government offices.

Layout and spatial boundary elements that become the transition zone:

The front center area of the complex has all garden attributes including signage of "City Hall Park", a statue, as well as a fountain pool, and a dominant green area on the sides which indicates the visitor has arrived at the informal zone directly.

\section{Spatial}

sequence

Description:

Formal

Informal 


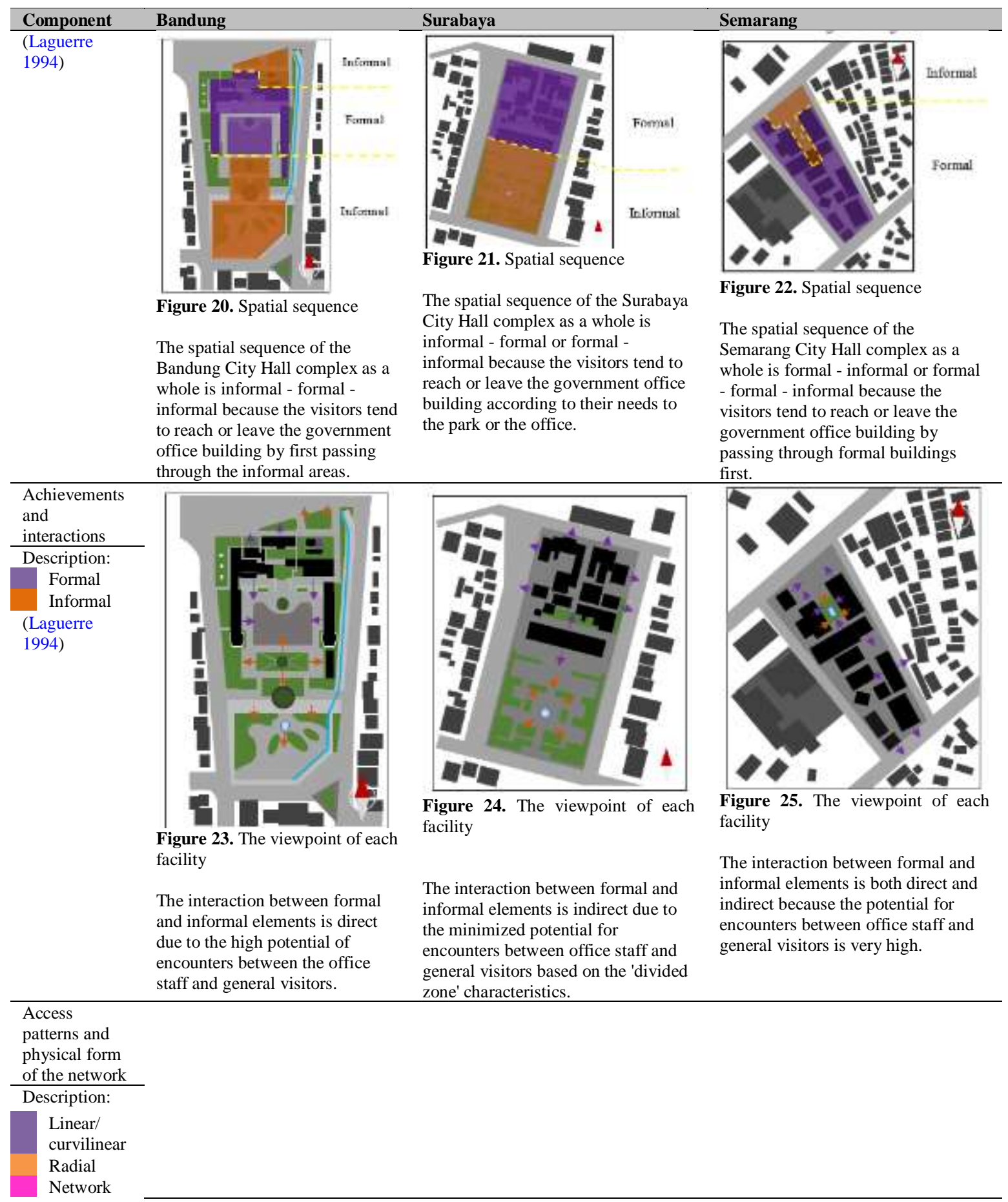




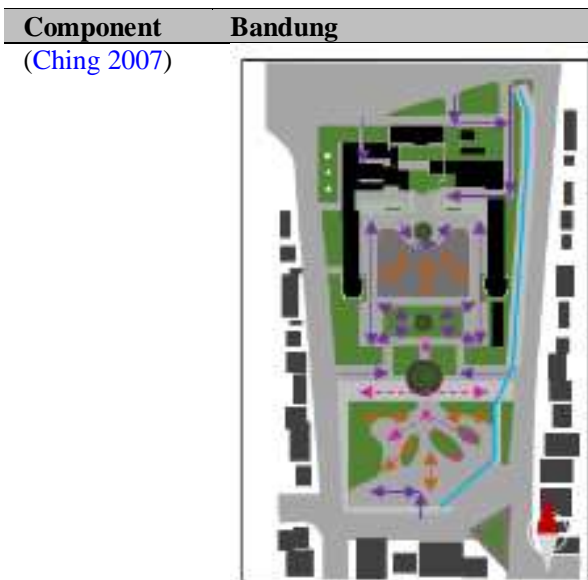

Figure 26. Movement patterns

The access pattern for the Bandung City Hall complex is composite due to its several landmarks/points/nodes consisting of thematic zone distribution which makes the visitor moves linearly, radially, or through networks.

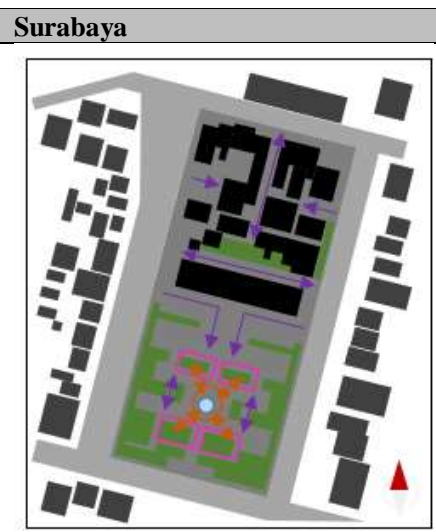

Figure 27. Movement patterns

The access pattern for the Surabaya City Hall complex is linear for formal government office areas because they are oriented towards 1-2 faces.

Meanwhile, the informal area is linear, radial for fountain, and grid for garden plots.

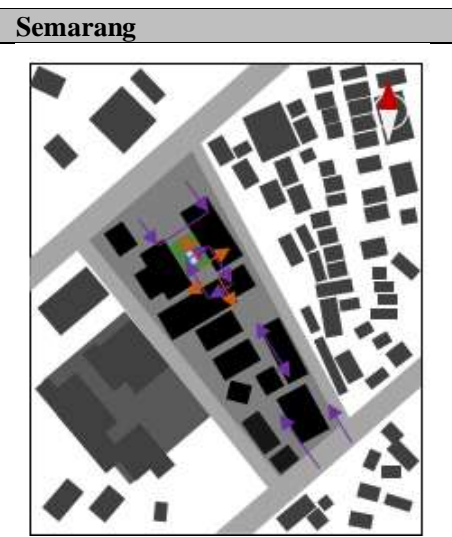

Figure 28. Movement patterns

The access pattern for the Semarang City Hall complex is linear and radial for the pond since the buildings in the office area have a physical form oriented to the 1-2 building faces.

The items of the components in table 7 were also analyzed and described as follows:

Table 7. Analysis of operational and formal-informal order

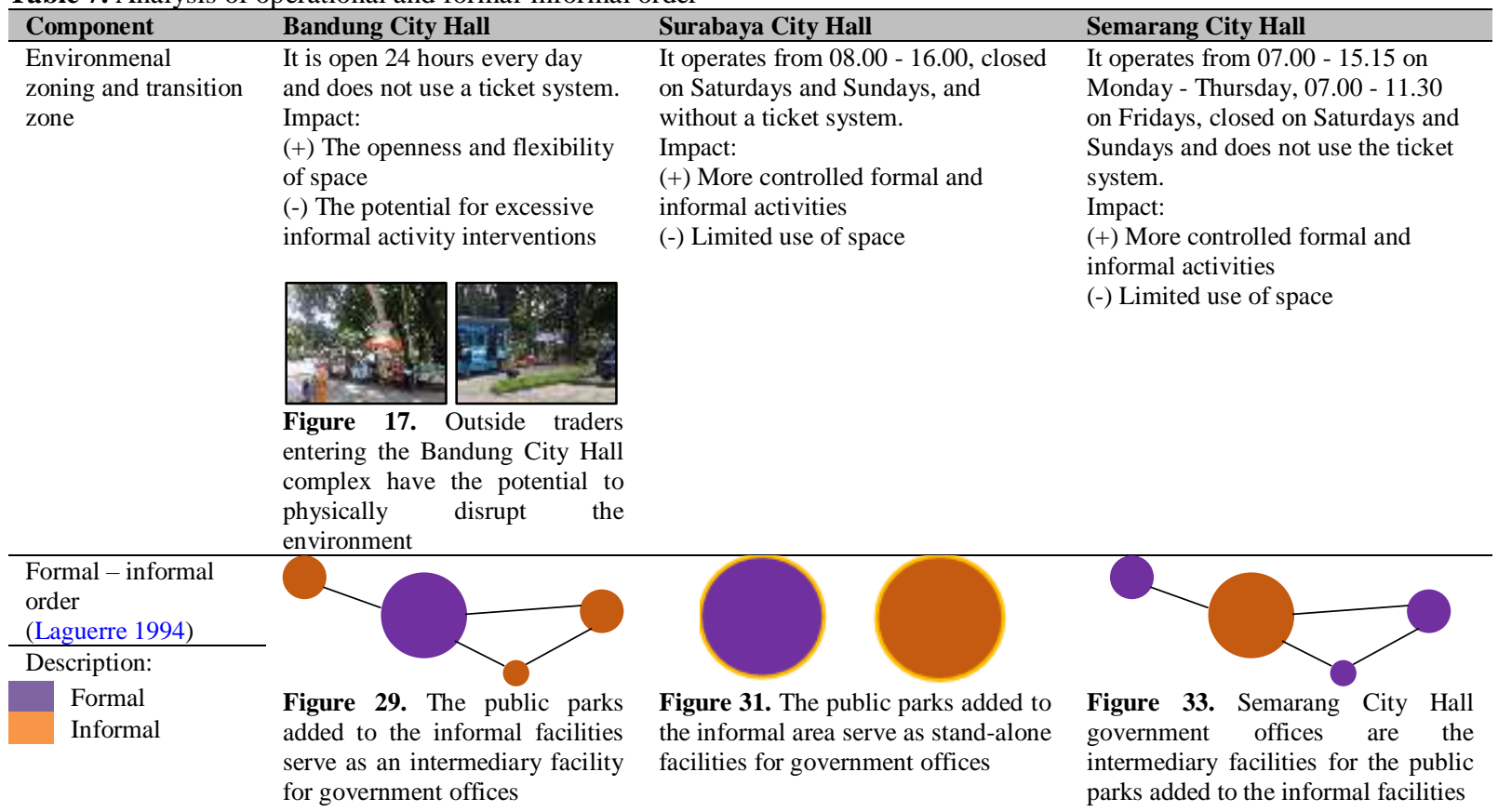




\begin{tabular}{lll}
\hline Component & Bandung City Hall & Semarang City Hall \\
\hline $\begin{array}{l}\text { Figure 30. Bandung City Hall } \\
\text { also has the ability to use the park } \\
\text { as a means of intervention }\end{array}$ & $\begin{array}{l}\text { Figure 32. The Surabaya City Hall } \\
\text { also has the ability to point out the } \\
\text { informal facilities as an intermediary }\end{array}$ \\
\hline
\end{tabular}

Table 8. Analysis of the overall physical order and the outer space system

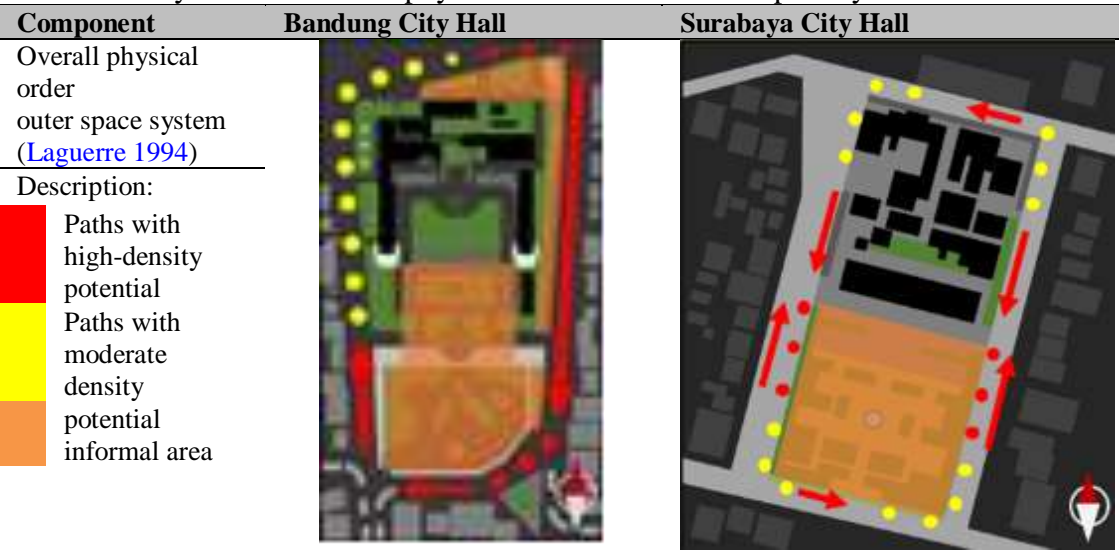

Figure 34. The processed informal part is observed from the outer space of the City Hall

1. The Bandung City Hall has an additional informal order surrounding the outer skin and assimilating in nature. 2. Having 4 roads that are equally active as alternative access.

Potentially congested roads: East and South directions Secondary roads: North and West directions

The resulting basic form variants:

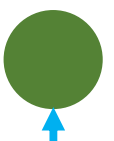

Figure 35. Physical order shows the openness and unity of space for the government and the public
Figure 36. The processed informal part is observed from the outer space of the City Hall

1.Surabaya City Hall has an informal area added in the form of a grid that is splitting in nature.

2. It has 4 roads equally active as alternative access.

Potentially congested roads: East and West direction. Secondary roads: South and North direction

The resulting Basic Form variants:
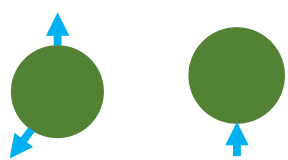

Figure 37. The physical arrangement shows an openness that can be 'divided' or 'unified' for the government and the public

\section{Semarang City Hall}

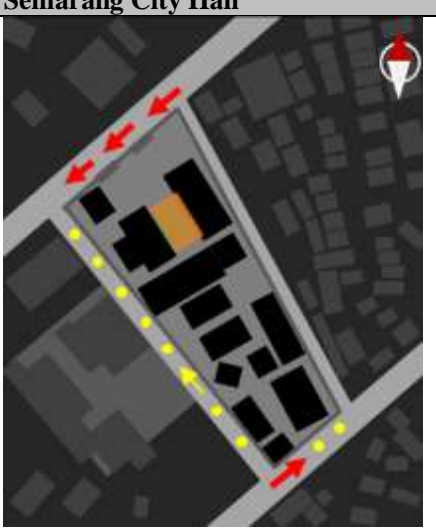

Figure 38. The processed informal part is observed from the outer space of the City Hall

1.Semarang City Hall has additional informal arrangements centered on the inside and which are assimilating in nature.

2.The space system of the Bandung City Hall has 3 roads considered to be equally active as alternative access.

Potentially congested roads: Northwestern and Southeastern directions. Secondary roads: West direction

The resulting Basic Form variants:

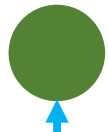

Figure 39. The physical arrangement shows the unity of space for the government and the public

\section{Analysis summary}

The stepwise analysis showed some of the results were synthesized into summary components which are further compared in the following tables (table $9 ; 10 ; 11$ ):

1. Transformation, permanence, and possession of spatial boundary elements 
Table 9. Transformation, permanence, and ownership of spatial boundary elements in the City Halls of Bandung, Surabaya, and Semarang

\begin{tabular}{llll}
\hline Conclusion components & Bandung City Hall & Surabaya City Hall & Semarang City Hall \\
\hline Location & Permanent & Permanent & $\begin{array}{l}\text { Changed: } \\
\text { Switch locations }\end{array}$ \\
\hline Function & $\begin{array}{l}\text { Changed: } \\
\text { Originally a coffee } \\
\text { warehouse }\end{array}$ & Permanent & Permanent \\
\hline Allotment & $\begin{array}{l}\text { Changed: } \\
\text { Originally intended for } \\
\text { European and interested } \\
\text { people }\end{array}$ & $\begin{array}{l}\text { Changed: } \\
\text { Originally intended for } \\
\text { European and concerned } \\
\text { people }\end{array}$ & $\begin{array}{l}\text { Changed: } \\
\text { Originally an area focused } \\
\text { on office activities }\end{array}$ \\
\hline Spatial boundary elements & $\begin{array}{l}\text { Fences, signage, flag fields, fountains/ponds, statues, pavement areas, parking lots, green } \\
\text { areas/gardens, office mass buildings and services, and guard posts. Each City Hall has the }\end{array}$ \\
& $\begin{array}{l}\text { same spatial boundary elements but only 1 (one) difference from the Surabaya City Hall } \\
\text { which is the absence of a statue element. }\end{array}$ \\
\hline Description & & \\
Difference & & \\
\hline
\end{tabular}

2. The factors determining the boundary arrangements to ensure control of environmental structures in City Government Central Offices
The components related to boundary order determinants are presented as follows:

Table 10. The influence of spatial boundary elements related to the digest of urban frame theory in Bandung,

Surabaya, and Semarang City Hall

\begin{tabular}{llll}
\hline $\begin{array}{l}\text { Conclusion components: } \\
\text { Determining factors }\end{array}$ & Bandung City Hall & Surabaya City Hall & Semarang City Hall \\
\hline $\begin{array}{l}\text { Environmental zoning and } \\
\text { transition zones }\end{array}$ & Mix & $\begin{array}{l}\text { Divided/Individual (offices } \\
\text { and parks) }\end{array}$ & Mix \\
\hline Spatial order & Informal - formal - informal & $\begin{array}{l}\text { Formal - informal and } \\
\text { informal - formal }\end{array}$ & $\begin{array}{l}\text { Formal - informal and } \\
\text { formal - formal - informal }\end{array}$ \\
\hline $\begin{array}{l}\text { Achievements and } \\
\text { interactions }\end{array}$ & Direct & Indirect & Direct \\
\hline $\begin{array}{l}\text { Access patterns and network } \\
\text { physical forms }\end{array}$ & $\begin{array}{l}\text { Composite } \\
\text { (linear/curvilinear, radial, } \\
\text { and network) }\end{array}$ & $\begin{array}{l}\text { Linear for office areas, and } \\
\text { linear radial and linear grid } \\
\text { for garden areas }\end{array}$ & Linear and linear radial \\
\hline $\begin{array}{l}\text { Description } \\
\text { Difference }\end{array}$ & & & \\
\hline
\end{tabular}

3. The embodiment of boundary arragements against central environmental control of City Government Offices
The summary components concerning the embodiment of the boundary order are presented as follows:

Table 11. Relationship and impact on the environment

\begin{tabular}{llll}
\hline $\begin{array}{l}\text { Conclusion components: } \\
\text { Embodiment }\end{array}$ & Bandung City Hall & Surabaya City Hall & Semarang City Hall \\
\hline $\begin{array}{l}\text { Overall informal } \\
\text { Governance }\end{array}$ & Assimilation & Separate, grid & Assimilation \\
\hline Outdoor system & $\begin{array}{l}\text { 4 active highways, 1 basic } \\
\text { shape variant pattern }\end{array}$ & $\begin{array}{l}\text { 4 active highways, 2 basic } \\
\text { shape variant patterns }\end{array}$ & $\begin{array}{l}3 \text { active highways, 1 basic } \\
\text { shape variant pattern }\end{array}$ \\
\hline Formal - informal & $\begin{array}{l}\text { 2 patterns, intermediaries, } \\
\text { and parasites from the } \\
\text { informal }\end{array}$ & $\begin{array}{l}\text { 2 patterns, intermediate and } \\
\text { stand-alone from formal and } \\
\text { informal }\end{array}$ & $\begin{array}{l}\text { 1 pattern, intermediate from } \\
\text { formal }\end{array}$ \\
\hline Proportion trend & $\begin{array}{l}\text { Informal }>\text { Formal, low } \\
\text { formal control environment, } \\
\text { dominant informal } \\
\text { environment }\end{array}$ & $\begin{array}{l}\text { Informal = Formal, } \\
\text { moderate formal control } \\
\text { environment, balanced } \\
\text { informal environment }\end{array}$ & $\begin{array}{l}\text { Informal < Formal, high } \\
\text { formal control environment, } \\
\text { dominant formal } \\
\text { environment }\end{array}$ \\
\hline Description & & & \\
\hline Difference & & & \\
\hline
\end{tabular}


Tables 9, 10, and 11 show how a public park serves an additional function in a City Hall and how the arrangement is influenced by the existence of space boundary elements. Meanwhile, these elements also support the identification of the determinants shaping the spatial boundary order, thereby, leading to variations in the basic forms and patterns of certain formal-informal relationships. Moreover, the control related to the environment was observed to be based on the tendency of the order to have potential positive and negative impacts such as spatial flexibility and interventions in public activities.

\section{Conclusion}

This research showed the order of public parks which are informal facilities in an office environment which is a formal facility is observed from the physical-spatial "boundary" aspect. Physically, the components of location, function, designation, and spatial boundary elements determine the basis for the order as the starting point, especially regarding transformation, permanence, and ownership of boundary elements.

Furthermore, the spatial effects including the components of environmental zoning and transition zones, spatial sequences, attainment, and interactions, as well as access patterns and network physical forms were deeply explored to understand the determinants of boundary structures. Once the physical-spatial order was understood, it was compared horizontally with wider manifestations including informal arrangements, outer spatial layouts, formalinformal relationships, and the tendencies associated with the public parks in the office environment or City Halls in Bandung, Surabaya, and Semarang.

The analysis showed that despite the similarities in ownership of spatial boundary elements of the structures, their forms for environmental control produce different variants of basic forms, patterns, and systems with advantages such as the flexibility and openness of space in an informal angle and disadvantages in the form of public intervention into private activities from a formal perspective. For example, Bandung City Hall was observed to have the lowest control from a formal perspective due to a wider proportion of informal arrangements but in an informal context and perspective, its existence has the highest flexibility and openness of space compared to the others. Meanwhile, Semarang and Surabaya City Halls do not have the same degree of openness as Bandung City Hall but they have conducive control over formal spaces and have the ability to minimize the occurrence of excessive intervention in formal activities.

\section{References}

Bukit, Elya Santa, Himasari Hanan, and Arif Sarwo Wibowo. 2012. 'Aplikasi Metode N. J. Habraken Pada Studi Transformasi Permukiman Tradisional'. Jurnal Lingkungan Binaan Indonesia (JLBI) 1 (1): 51-62. https://jlbi.iplbi.or.id/wpcontent/uploads/2012/07/V1N1-p051-p062Aplikasi-Metoda-N.J.-Habraken-pada-StudiTransformasi-Permukiman-Tradisional.pdf.

Ching, Francis D. K. 2007. Architecture: Form, Space, and Order. 3rd ed. New Jersey: John Wiley \& Sons, Inc.

Dianty, Grace Putri, and Yohanes Basuki Dwisusanto. 2020. 'Aktivitas Di Alun-Alun Sebagai Ruang Terbuka Publik Dengan Konsep Lapangan, Kasus Studi: Alun-Alun Bandung'. ARTEKS : Jurnal Teknik Arsitektur 5 (1): 47-56. https://doi.org/10.30822/arteks.v5i1.116.

Garvin, Alexander. 2011. Public Parks, The Key to Livable Communities. New York: W. W. Norton \& Company Inc.

Habraken, N. John. 1998. The Structure of the Ordinary, Form and Control in the Built Environment. Edited by Jonathan Teicher. Paperback. Cambridge: MIT Press. https://www.habraken.com/html/structure_of _the_ordinary.htm.

Hanan, Himasari. 2013. 'Open Space as Meaningful Place for Students in ITB Campus'. Procedia - Social and Behavioral Sciences 85 (September): 308-317. https://doi.org/10.1016/j.sbspro.2013.08.361.

Handinoto. 1993. 'Arsitek G. C. Citroen Dan Perkembangan Arsitektur Kolonial Belanda Di Surabaya (1915-1940)'. Dimensi 19: 1-16. 
https://adoc.pub/arsitek-gc-citroen-danperkembangan-arsitektur-kolonial-bela.html.

Hantono, Dedi. 2019. 'Kajian Perilaku Pada Ruang Terbuka Publik'. NALARs 18 (1): 45. https://doi.org/10.24853/nalars.18.1.45-56.

Harahap, Akhir Matua. 2017. 'Poestaha Depok'. Poestaha Depok. 2017. https://poestahadepok.blogspot.com/search?q $=$ Harahap.

Hartoyo, Hansen, and Santoni. 2018. 'Kriteria Ruang Publik Kalijodo Pendukung Aksesibilitas Dan Peningkatan Aktivitas'. ARTEKS: Jurnal Teknik Arsitektur 2 (2): 113-24. https://doi.org/10.30822/arteks.v2i1.45.

Hidayati, Hana Eka, and Roni Sugiarto. 2020. 'Peran Tatanan Elemen Arsitektural Terhadap Pembentukan Soundscape Pada Ruang Terbuka Publik Balai Kota Bandung'. Riset Arsitektur (RISA) 4 (04): 350-62. https://doi.org/10.26593/risa.v4i04.3938.350362.

Irfandi, Mirza, Irzaidi, and Khairul Huda. 2017. 'Pengaruh Kualitas Fisik Ruang Terbuka Publik Aktif Perkotaan Terhadap Kualitas Hidup Masyarakat'. In Temu Ilmiah Ikatan Peneliti Lingkungan Binaan Indonesia 6, A023-30. Banda Aceh: Ikatan Peneliti Lingkungan Binaan Indonesia. https://doi.org/10.32315/ti.6.a023.

Irwanto, Deny. 2017. 'Proyek Taman Balai Kota Senilai Rp 1,7 Miliar Membuat Kecewa Hevearita, Begini Alasanya'. BeritaSemarang. 2017.

https://www.beritasemarang.net/proyektaman-balai-kota-senilai-rp-17-miliarmembuat-kecewa-hevearita-beginialasanya/5087/.

Kunto, Harjoto. 1984. Wajah Bandoeng Tempoe Doeloe. Bandung: Granesia.

Laguerre, Michel S. 1994. The Informal City. New York: St. Martin's Press, Inc.

Liem, Yoseph, and Reginaldo Chistophori Lake. 2018. 'Pemaknaan Ruang Terbuka Publik
Taman Nostalgia Kota Kupang'. ARTEKS: Jurnal Teknik Arsitektur 2 (2): 149-58. https://doi.org/10.30822/arteks.v2i1.48.

Maslow, Abraham. 1954. Motivation and Personality. New York: Harper.

Suriastuti, Mira Zulia, Deddy Wahjudi, and Bagus Handoko. 2014. 'Kajian Penerapan Konsep Kearifan Lokal Pada Perancangan Arsitektur Balaikota Bandung'. Jurnal Itenas $\begin{array}{llll}\text { Rekarupa } & 2 & \text { (1): } & \text { 122-28. }\end{array}$ http://jurnalonline.itenas.ac.id/index.php/reka rupa/article/view/710.

Trancik, Roger. 1986. Finding Lost Space: Theories of Urban Design. Finding Lost Space. New York: John Wiley \& Sons Inc.

Viantara, Risma. 2020. 'Analisis Taman Tematik Sebagai Ruang Terbuka Publik Di Kota Bandung'. Geoplanart 3 (1): 46-56.

Wibowo, Ari, and Mangasa Ritonga. 2018. 'Kebutuhan Pengembangan Standar Nasional Indonesia Fasilitas Taman Kota'. Jurnal $\begin{array}{llll}\text { Standardisasi } & 18 & \text { (3): } & 161 .\end{array}$ https://doi.org/10.31153/js.v18i3.234.

\section{Author(s) contribution}

Titania Aulia contributed to the research concepts preparation, methodologies, investigations, data analysis, visualization, articles drafting and revisions.

Yohanes Karyadi Kusliansjah contribute to the research concepts preparation and literature reviews, data analysis, of article drafts preparation and validation.

Hartanto Budiyuwono contribute to methodology, supervision, and validation. 
ARTEKS : Jurnal Teknik Arsitektur, Volume 6 Issue 3, December 2021

pISSN 2541-0598; eISSN 2541-1217 